\title{
The Existentially Analytical Approach to Value of Life
}

Marie Lhotová

\section{Points of departure and sources of logotherapy and existential analysis}

Logotherapy and existential analysis are classified as humanist-oriented psychotherapeutic approaches. They derive from the positions of existentialism, phenomenology and holism. Their original sources were especially the works of the existentialist Søren Kierkegaard, theologians Thomas Aquinas and Augustine Aurelius, as well as works of the phenomenologically oriented philosophers Max Scheler, Edmund Husserl, Martin Heidegger. Viktor Emil Frankl embodied their ideas into the foundations of his teaching and gradually developed them. Max Scheler is most often regarded as the spiritual father of logotherapy and existential analysis; concurrent thought similar to Frankl's, but with different conceptual equipment, can be found in Karl Jaspers. The central point of Jaspers' philosophy is the gravity of decision-making in human existence, in Scheler the central point are values and emotions related to them. The aim of this text is to show how Frankl's existential analysis and logotherapy and its new form extended by the thought incentives of Frankl's direct pupil Alfried Längle works with the topic of deciding to life, with the value of life and responsibility for life and its values. Cakirpaloglu underlines that Frankl's conception is directly constructed on values around the central concept of meaningfulness of life, and these are closely linked to the ethical and experiential dilemmas of the present. ${ }^{1}$ Frankl's conception of values and meaning of life is described as individualistic, humane, following the line of ethical empiricism which denies transcendentalism and apriorism of the moral and value factors of human action. ${ }^{2}$ The American Journal of Psychiatry labels Frankl's work as "perhaps the most significant since Freud and Adler". ${ }^{3}$ Marshall and Marshall further mention the opinion of G. Allport, who describes logotherapy as "...the most significant psychological movement of our day". ${ }^{4}$

\subsection{Definition of existential analysis}

This chapter aims to show how logotherapy and existential analysis insert the topic of value of life in its theoretical framework. With this aim we conceive its definition. Existential analysis and logotherapy derive from Frankl's anthropological conception of human, in which two concepts - existence and person - are especially prominent and in whose foundation two questions blend - what specifically human makes a human being human and what enables a human being to live a fulfilled life. Frankl starts from dimensional ontology and describes the human being in three mutually linked levels of human existence - physical, psychological and spiritual. ${ }^{5}$ In existential psychotherapy analysis is used in work with the patient to find the value of life for maintaining or enabling meaningful existence. The effort is to analyse the conditions of existence and dissolve what prevents existential living.

\footnotetext{
1 Cf. Panajotis CAKIRPALOGLU, Psychologie hodnot: Přehled pro humanitní obory, Olomouc: Votobia, 2004, p. 276.

2 Cf. ibid.

3 Maria MARSHALL - Edward MARSHALL, Logotherapy revisited. Review of the tenets of Viktor E. Frankl's logotherapy, Ottava: Institute of Logotherapy, 2012, p. XIV.

4 Ibid.

5 Cf. Martina KOSOVÁ, Logoterapie. Existenciální analýza jako hledání cest, Praha: Grada Publishing, 2014, p. 14; @ Martin WAGENKNECHT, Rozpracování logoterapie a existenciální analýzy v GLE (on-line), at: http://www.slea.cz/index.php?page=mw6, retrieved January $17^{\text {th }}, 2015$.
} 
Existence is an ontological concept from the Latin word existentia-ex-sistere, ${ }^{6}$ or ek-sistó, - close in meaning to the English words rest outside, occur, step out, go out, come up, appear, show, be, or the nouns occurrence, external manifestation, i.e., movement outside towards something being able to arise and be. The word existence is often used as a synonym to the concept of being or being here. This translation reminds of another existential orientation - the daseins-analysis of Ludwig Binswanger and his most famous pupil Medard Boss -, whereby it at the same time shows how different perspectives can be utilised in practical psychotherapeutic work with similar topics. In both approaches ex-sistere means to enter life. The concept of existence in Frankl also means living with self-surrender, devoting oneself to something without abandoning oneself and giving oneself up in the interest of the thing.

Existential analysis is a psychotherapeutic approach which examines the phenomenological substance and analysis of conditions to fulfilling life, ${ }^{7}$ i.e., what conditions must be met in order for the human being to live a fulfilled life, and how existence is possible in the life of a human being in the midst of the conditions she lives in. In that it regards the spiritual and psychological transformation and real change of situation in the world of a particular human being and raises the question whether the human being can internally assent to what she does or does not do.

Existential analysis and the ways it works, especially biography, deal with the question why the human being is incapable of dialogue, whereby this dialogue is given by the fact that the human being begins to realize the values she sees in the world. Besides work on self-development, which is the domain of the client-oriented psychotherapy of $C$. Rogers, in the practice of existential analysis there has appeared effort to work on ways how the human being can respond to the demands of life and thereby fulfil it. Precisely existential fulfilment is being in the dialogue of the I-situation. The criterion of inner fulfilment can then be expressed with the sentence "it is a good life I live". The human being fulfils her existence when she is addressed by her situation to which she is able to respond. A condition of being addressable by the situation is the courage to give oneself to it. As soon as a vacuum at this level arises, space is made for various disorders, addictions and experiences of states of external threat. In a certain sense existential analysis stands in contrast to psychoanalysis, because it has a different focal point in that it sees the task of the human being in stepping outside of herself and entering dialogue with the world.

Frankl himself originally regarded logotherapy as supplementation and integration of Freud's psychoanalysis and Adler's individual psychotherapy, but later he saw existential analysis as a theory which is the foundation of psychotherapy. He understood existential analysis to be a theoretical-investigative orientation dealing with the ontological level of existence, i.e., interpretation, possibilities and conditions of fulfilled existence. When Frankl was still alive, two thought approaches developed. One is represented by Elisabeth Lukas from Süddeutsches Institut für Logotherapie, who develops her approach in the original Franklian conception of logotherapy as supplementation of psychotherapy. Alfried Längle from the Vienna society Gesellschaft für Logotherapie und Existenzanalyse as representative of the second approach understands logotherapy to be a counselling method oriented at meaning. In Balcar's words existential analysis is a path of knowledge and logotherapy is a path of help. ${ }^{8}$ According to

6 Cf. () Lateinwörterbuch (on-line), at: http://www.frag-caesar.de/lateinwoerterbuch/exsistere-uebersetzung.html, retrieved June $17^{\text {th }}, 2015$.

7 Cf. @ Karel BALCAR, Materiály z výcviku Společnosti pro logoterapii a existenciální analýzu, Praha, 1992-1998, at: http://www.iqle.cz/ dokumenty/frankl.pdf, p. 20, retrieved January $2^{\text {nd }}, 2015$.

8 Cf. ( ) Karel BALCAR, Logoterapie a existenciální analýza Viktora E. Frankla (on-line), at: http://www.slea.cz/old/index.php/odborne-textymainmenu-2/2009/05, retrieved June $17^{\text {th }}, 2015$. 
Lukas logotherapy is psychotherapy oriented at meaning. ${ }^{9}$ The psychotherapists of the Vienna school GLE ${ }^{10}$ define logotherapy as a counselling orientation which helps the patient in re-evaluating her life to find a value system she could regard as meaningful, in a situation when she cannot see the values of the situation. As such logotherapy is a specific area of existential analysis, which focuses on what possibilities are opening for the client in the world. Existential analysis is regarded as a psychotherapeutic approach aiming to make the human being capable of internal assent to being able to live by her action and being ${ }^{11}$ and be ego-syntonic. Transition from logotherapy to existential analysis occurs at the moment of realising that although the patient cognitively understands what she could do, she is not capable of living her values. In this sense there is a difference in the sphere of indications. Existential analysis asks why it is impossible for the human being to see, distinguish, will and realize values. It works more often with depth dynamic, while logotherapy combines well with behavioural therapeutic methods. Frankl himself eventually defines the two approaches in relation to the spiritual as psychotherapy deriving from the spiritual and psychotherapy heading towards the spiritual, to existence. ${ }^{12}$ In the former case such psychotherapy is presented as logotherapy, in the latter as existential analysis.

Kosová, an important representative of Czech logotherapy, emphasizes the same philosophical points of departure of these approaches. ${ }^{13}$ The substance of the two approaches is the same, can be expressed by the goal, which is "...to help the human being to a spiritually and emotionally free experiencing, to authentic, genuine, true, own attitude-taking and responsible treatment of one's life and one's world". ${ }^{14}$ The specific form of work in existential analysis is seeking the answer YES to one's life with use of the following structure of motives.

\subsection{Personal motivation/conditions for existence}

Existential analysis and logotherapy in the conception of the Vienna school GLE conceives Frankl's "will to meaning" as the deepest human motivational force. Besides the issue of meaning it focuses on the conditions enabling fulfilled life. The casuistry which is part of this paper is based on Frankl's conviction that human life always carries in it the possibility of meaningful fulfilment even in difficult life conditions through realization of values. For the reason of grave distortion of attitude to the value of life in the patient, the practical work has made use of the method of gradual elaboration of life conditions with the goal of arriving at accepting them.

YES to life is contained in four main conditions. Each of these four basic conditions contains relationship to life as the experience that the human being can be, can love herself as a value, the experience that she can be what she is like. YES expressed to these three motives gives one the possibility to understand the meaning of her own full life bound in theory to the fourth, transcendental plane.

\subsubsection{Accepting life (Kann ich sein?)}

The content of the first motive is the issue of the foundation of being, i.e., accepting life.

9 Cf. Elisabeth LUKAS, Von der Trotzmacht des Geistes. Menschenbild und Methoden der Logotherapie, Freiburg: Herder, 1993; Martina KOSOVÁ, Logoterapie. Existenciální analýza jako hledání cest, p. 14.

10 Gesellschaft für Logotherapie und Existenzanalyse based in Vienna at Heumühlgasse 11, see www.existenzanalyse.at.

11 Author's archive, Book 1, Jana BOŽUKOVÁ, Materiály z výcviku Společnosti pro logoterapii a existenciální analýzu, Praha, $1992-1998$. Unpublished.

12 Cf. Viktor E. FRANKL, Vưle ke smyslu: Vybrané přednášky o logoterapii, Brno: Cesta, 1997, p. 126.

13 Cf. Martina KOSOVÁ, Logoterapie. Existenciální analýza jako hledání cest, p. 14.

14 Author's archive, Book 2, Jana BOŽUKOVÁ, Materiály z výcviku Společnosti pro logoterapii a existenciální analýzu, Praha, 1992-1998. Unpublished. 
Accepting life means a positive answer to the question about the existence of living space where one can be and what one can hold on to in her life, so that life can be protected and that one can act in it. This has to do with intelligible life structures, trust, faith and loyalty. The physical representative of the possibility to be is breathing as the bearer of a fundamental life function. At the psychological level the aim is to "be able to accept one's life and also be accepted" ${ }^{15}$ Symptoms of not accepting oneself and one's life conditions are aggressive states, escaping from reality, distrust, in the clinical image there are somatic illnesses often in the area of respiratory organs and psychotic disorders. ${ }^{16}$

\subsubsection{Wish for life (Mag ich leben?)}

The second issue concerns the emotional dimension of the human being, the fundamental value of existing, which requires one to incline to her life, to experience affection, say YES to how she experiences it. It means not only that she can, but that she wants to live and be glad to be alive. In that she consents to the fact that life means to enjoy as well as suffer, to love, experience pain, be affected. It is a matter of a fundamental experience of the value of life formed on the basis of experiences of oneself with the external and internal world. Assenting to the fact that one lives brings her to the world and its values. The clinical image of not accepting the fundamental value of existing at the level "I want" are depressive states with the experience that life is so demanding that it is not good to live it. In depression there lacks vitality and emotional relationship to values is lost. The physical representative is the heart and circulation. ${ }^{17}$

\subsubsection{To be allowed to be oneself in one's life (Darf ich sein?)}

In the third issue there appears the ethical question: Am I allowed to be as I am? This issue requires one to say YES to one's life, to oneself and one's uniqueness. The basic feeling is the feeling of one's own value. One must be able to withstand that she is alone in her life and that only she can be herself. The danger is fear of solitude and desertedness, in which one can be threatened by not finding or losing herself. The lost person then seeks herself in various forms, roles and various activities and/or addictions. The clinical image is personality disorders, especially histrionic, dependent and paranoid ones. The physical representative is the stomach. ${ }^{18}$ The therapeutic aim in this phase is to teach the patient to find and maintain a healthy critical distance from herself, enabling her to approach others as well as herself with respect.

\subsection{Existential motivation/condition - self-transcendence}

This condition is aimed at the spiritual dimension of the human being. In the view of existential analysis the spiritual dimension is given by the human being's unique possibility to cognize values. Längle remarks that life means that the human being is oriented at realities she does not determine herself, and that not only what she wills and wishes can be her life reality. ${ }^{19}$

\subsubsection{The human being is a part of the world - ought to make life better (Was soll werden?)} The last of the four motivations which existential analysis defines for possibilities of meaningful living is given by openness to life and answer to the question what tasks, challenges and

\section{Ibid.}

16 Author's archive, Marie LHOTOVÁ, Výpis z klinickopsychologického vyšetření dle osobnostních dotazníků a projektivních materiálů; Kyzourův test barevných pozic. Unpublished. Cf. Samuel E. KRUG - Raymond B. CATTELL, Dotazník klinické analýzy, Bratislava: Psychodiagnostika, 1998.

17 Author's archive, Marie LHOTOVÁ, Výpis z klinickopsychologického vyšetření dle osobnostních dotazníků a projektivních materiállo: Kyzourův test barevných pozic. Unpublished. Cf. Radek PTÁČEK - Hana KUŽELOVÁ - Michaela BOROVANSKÁ - Adéla RUDÁ, Hareho škála psychopatie, $P C L-R$.

18 Cf. Ján PRAŠKO et al., Poruchy osobnosti, Praha: Portál, 2003, pp. 269-271, 321-324.

19 Author's archive, Book 3, Alfried LÄNGLE, Materiály z výcviku Společnosti pro logoterapii a existenciální analýzu, 1998. Unpublished. 
requirements life gives, what ought to be in the particular life and how one can come to terms with it, how to handle it, what can be done with what is currently happening. For the human being these issues mean to be questioned and also doubted, with the fact that one comes closest to life when she responds to the challenges. From the existential point of view the ideal is that one can be herself with respect to the offers and situations of her life. The task is to cope with life and take care of it.

\section{Life as a value}

The word life is a common word, very frequent in human speech. For reflections on the value of life it is expedient to recall two related meanings of this concept. Sokol's distinction between "my life" and "life in general, as such" will be helpful in this. ${ }^{20}$ One's own "my life" can be conceived as an inner and private world, in the term of the Spanish philosopher Ortega y Gasset biographical life. ${ }^{21}$ Life "as such" is in this context biological life comprising "all that lives, not only in its present contexts, but also in the 'diachronic' context of the past, from which all living comes, and the future, which awaits it". ${ }^{22}$

In contexts with a therapeutic goal existential analysis is oriented at the individual, unique life from birth to death. This own biographical life is what each adult must take care of. Heidegger characterizes human life in the sense that "in his being this being itself is concerned".$^{23}$ In this conception life is a synonym of existence, dasein, being and in the conception of Wittgenstein, ${ }^{24}$ whose statement recorded in his diary of 1916 is quoted by Sokol, also the world. The statement "life and the world are one" and "of course physiological life is not 'life' and neither is the psychological one" returns us again to the more complex space of human nature. Our being situates us face to face with the fundamental question of relationship to life, which is "I wish" or "I do not wish to live". ${ }^{25}$ To love life one needs three conditions according to existential analysis: relationship, time and closeness. If these conditions are missing, there appears first desire, then coldness and finally depression as a symptom of "I don't want to live". The value of life disappears.

In work with motivations and emotions and to them related deepest experiences existential analysis gradually attains a sense of the value life as such has. This value becomes the absolute value. It is reflected in the substance of the experience of all values there are in life. In therapeutic work it appears in the system of universal, individual and personal values.

Tavel describes the loss of value of human life and dignity of the human person with a quotation from Frankl in the situation of an individual who "becomes the exclusive object of the will of others. Unless he resists this with an extreme bracing of the sense of dignity of his own life, he loses sense of the fact that he is still a subject, that he is a spiritual being with some internal freedom and personal value, loses thinking and will, is merely an element of the mass." 26

\footnotetext{
20 Jan SOKOL, Etika a život: Pokus o praktickou filosofii, Praha: Vyšehrad, 2010, p. 31.

21 Cf. ibid, p. 30.

22 Ibid, p. 30.

23 Martin HEIDEGGER, Bytí a čas, Praha: OIKOYMENH, 1997, p. 41.

24 Cf. Jan SOKOL, Etika a život: Pokus o praktickou filosofii, p. 30.

25 Cf. Alfried LÄNGLE, Smysluplně žít: Aplikovaná existenciální analýza, Brno: Cesta, 2002, p. 44.

26 Peter TAVEL, Smysl života podle Viktora Emanuela Frankla: Potřeba smyslu života. Př́nos Viktora E. Frankla k otázce smyslu života, Praha/ Kroměříz: Triton, 2007, p. 129.
} 


\subsection{Life in time}

A part of the view of life is its temporality. The temporal aspect perceived in the following casuistry opens the question of the duration of abiding in sorrow and crisis. Human life is set in time. We are temporal beings because there is a beginning and an end to earthly life. Developing the ideas of Bollow, Christine Wicky understands the past, the present and the future as three directions in which the temporal behaviour of the human being extends and of all of which the present moment is formed. All three temporal dimensions have the character of reality e.g. in that one can experience the effects of the incidence of the past and the future. One experiences them as of mutually equal value, she can experience e.g. the past as something that slows down or, on the other hand, as something that gives ground to stand on. The movement of life is not directed to death but is thrown back to life. ${ }^{27}$ Existentially analytical reflections on human life present time as the existential foundation and condition on which human being is realized in time. Death is conceived as something that will take place in the future, but at the same time it is a motivating and formative part of the present life now. Uncertainty concerning the hour of death forces one to live so that what gives meaning to her life does not consist in something that will happen in the future. If one wants to stand the test face to face with death, she is challenged to organize her life so that fulfilling its meaning will be contained in the present. She is referred to what is essential in her present living, when she is called to the resolution of true existence. ${ }^{28}$ Kosová mediates being prepared for death by references to closeness, openness and truthfulness. ${ }^{29}$

\subsection{Types of values for fulfilling life}

Frankl simplified Scheler's complex doctrine of values by distinguishing three types of value expressing relationship to the world with respect to fulfilling life. In the Franklian teaching creative, experiential and attitudinal values are three paths to life filled with meaning. We find creative values in the form of deeds which the human being (homo faber, creator, originator, producer and artist) presents to the world in the form of work; we find experiential values when the human being (homo amans, the loving human) seeks and from the world obtains relationships and beauty; attitudinal values when the human being (homo patiens, the suffering human, capable of bearing suffering, hardy, enduring, patient) finds reasons for life even with suffering and is capable of changing her attitude to life and suffering. The basis of how to lead one's life are the primary values for being - experiential and creative. For coping with life the highest values are the attitudinal ones, in which facing up to inevitable suffering is superior to primary values. "The difference among the three value categories and the continuous sequence of possibilities how to realize them in life implies nothing less than that life for which we have assumed responsibility means always and in all circumstances, in every situation a task for us. But thereby it has also been proved that in each individual moment our existence has an ever different, ever changing, but always some meaning. Also difficulties, however great they may be, are only of such kind that they intensify the character of our existence as task, and thereby intensify the meaning of life." ${ }^{30}$ In the view of existential analysis and logotherapy relationship to life here in the world is linked to the uncertain question what being here is good for. What should one live for? A process of seeking meaning takes place in life which is personal and very specific for the human being. Every way of coping with life is subject to the question of its meaningfulness.

27 Cf. Christine WICKY, Časovost jako výzva k pravé existenci, in: Žít svůj vlastní život, ed. Silvia LÄNGLE - Martha SULZ, Praha: 
What has been said above implies that life can be either lived and formed or endured, that seeking meaning can be identified with life and that the value of life is given by meaning, whereby values, including the value of life, are the essence of meaning.

Frankl perceives the human being in a dynamic relationship to her meaning, he sees meaning in the centre of human life. Although he criticizes the contemporary human who has lost the sense of meaning and escapes to workaholism and various enjoyments, he is nonetheless convinced that the human being is concerned "primarily and ultimately with meaning and nothing but meaning". ${ }^{31}$ The human being is not the one who should ask what her life is for, but the one who is asked by life and "ought to respond and be responsible to life" ${ }^{32}$ Existential meaning is understood as a challenge and as the best possibility of the given situation against the background of the given reality. Frankl speaks of higher, definitive absolute meaning, which in contemporary existential analysis is called ontological meaning. We cannot know this ontological meaning, we must believe in it. It expresses the meaning of the whole in which one finds herself, it is understood either philosophico-ontologically, when everything one undergoes has some higher, absolute meaning, or religiously, when the meaning is given by the Creator and one is able to live it when she is in a dialogical relationship to the world and is open to what comes and speaks to her from the world, is open to herself, to the situations in her life, values and questions. In the conception of existential analysis, to live means to respond to the questions of the present moment. The ability to experience existential meaning gives the possibility to experience ontological meaning. ${ }^{33}$

As the basic three pillars of logotherapy M. Marshall and E. Marshall designate freedom of the will as the anthropological basis of logotherapy, ${ }^{34}$ will to meaning as the basis of psychotherapeutic theory ${ }^{35}$ and meaning of life as philosophy. ${ }^{36}$

Trust, which spans uncertainty and enables a positive relationship to life, shows the basal attitude to life. Such trust is linked to the ability to take and give. When we extend the view to inter-human giving and taking, we can in a parallel see giving and taking from life itself. We long for life filled with self-esteem, for life filled with the certainty that we can stand for ourselves.

\section{Life as the basic value}

As long as one lives she is incessantly in a relationship to her being in this world. She gradually forms her own attitude to life. In dealing with life there appear attitudes of accepting, refusing or waiting. The more values of the world get through to the human being, the more intensively she accepts life.

Basic value arises as a result of the fact that life was accepted in its very beginning. The first factor affecting the arising of one's basic value and acceptance of life is how she was welcomed and expected and accepted in this world due to those who were well-disposed to her, who are a joy to her, she herself is a joy to them. Due to this she experiences affection for herself. By positive relationship to herself she loses dependence on others. Induction of basic value is

31 Ibid, p. 74.

32 Viktor E. FRANKL, Logotherapie und Existenzanalyse, München: Piper, 1987, p. 141.

33 Cf. ibid, p. 141.

34 Cf. Maria MARSHALL - Edward MARSHALL, Logotherapy revisited: Review of the tenets of Viktor E. Frankl's logotherapy, p. 8.

35 Cf. ibid, p. 21.

36 Cf. ibid, p. 28. 
therefore mediated by another human being, by the beauty of the world and by the experience of her being. The basic value is the already mentioned assent to own life when answering the question: What is the fact that I live like for me? It expresses the attitude to the deepest emotionally appreciable quality of own being ${ }^{37}$ given by emotional experiencing of life in its everyday forms.

In individual psychotherapeutic work relating to the issue of value of life existential analysis often proceeds by the biographical method taking into account the above stated aspects at present and in the past, by phenomenological analysis and eventually by reconstructing attitudes. These methods also illuminate traumas and long-retained deformed attitudes leading to painful experiences, the principal of which is destabilization in one's relationship to the question: "Do I want to live?" They try to lead the client to being touched by the world, so that she gets in a relationship to her life and is well-disposed to her life. Where basic value is missing neurotic states, states of exhaustion and/or depression occur. In work with some clients the lived trauma loses strength already in the biographical part, when recapitulating life and searching for sources of the voices saying that it is not good to live, while with other clients leading to a relationship to life is very demanding.

The aim of chapters 1-3 was to outline the theoretical background of the topic of value of life from the perspective of logotherapy and existential analysis, which could serve as a basis for references and perspectives of the processual level of psychotherapeutic work described in the following casuistry.

The casuistry aims to illustrate the principles of this approach in practical work and point to the central issue of loss of meaning of life and limits of solving it that can occur in every psychotherapeutic encounter. It tries to capture and document the therapeutic course of events in narrative form and prompt to reflection on the patient's and therapist's share in interactions within the therapeutic relationship. Analysis of the casuistry rests on gradual identification of issues testifying to the direction of insight in motivations to life and other aspects which are the supporting potential and seeking the links which constituted the therapeutic context and the context of the patient's life. It leads to the definition of the two categories on which the analysis itself rests (Losses and To have something to live for). In the concluding interpretation of the analysis we look for links beyond the framework of formal theory which should provide space for reflection on the reason why positive shift and finding meaning has not occurred in the patient's life. The casuistry shows the framework within which the thinking of the given orientation was organized. It does not belong among the "well solved" ones, which is why it is written with therapeutic humility and publishing anxiety.

\section{On the method of the therapeutic work}

The work with the patient derived from the concept of basic motivations - the four fundamental categories of existence - and had the goal of elaborating the relationship to the world; the vitally axiological dimension of the work was aimed at elaborating the relationship to life, the ethical dimension was aimed at the relationship to oneself and the practical level was to form relationship to the future. Art therapeutic and imaginative procedures, recalling and supportive therapy were used to supplement. The originally planned de-reflection and paradoxical intention could not be used due to the gravity of the patient's state. 


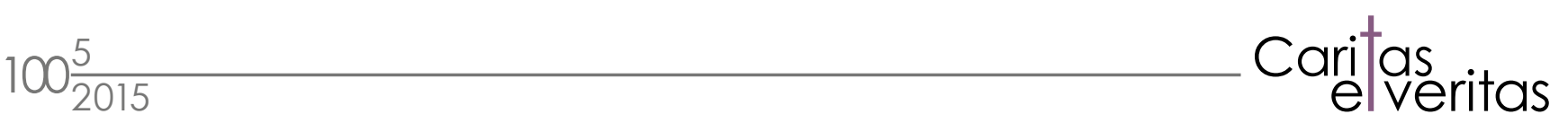

The method of personal existential analysis presupposed work on the patient's dialogue with the world, because as a result of trauma the patient had lost openness to himself and the world. In the first step having to do with experience I tried to work on re-awakening his lost emotionality, subsequently on enabling him by means of self-distance to find in the world of his emotions the source of taking an attitude which would allow him to grasp the value of life again.

\section{Casuistry}

When there appears in life (and therapy) the conviction My life is worthless

The selected part of the case study describes the gradual loss of life value in a 50 year old man, Mr. J., in a situation which is not uncommon in human life-stories - in the situation of divorce. Its purpose is not to point out how successful logotherapy and existential analysis are, but rather how difficult it is with sudden absence of meaning of life and subsequent loss of its value to establish a therapeutic shift to re-finding meaning. It therefore reflects the limits of both participants in the psychotherapeutic process.

\subsection{Beginning and progress of therapy}

Mr. J. was treated for fairly serious sleep disorders. After half a year of coming to individual psychotherapeutic sessions he arrived with a totally new problem. His wife had allegedly totally without warning filed a divorce application. Mr. J. was full of uncertainty and anxiety, he was dismayed, but because he thought that they had got along well he refused to believe that it could really have happened. He demanded assurance that it can't be true. He carried the ideal of the exemplary Christian family within him and up to the present had not noticed any changes in the behaviour of his wife that would signal a change in their relationship to him. The effort in this phase was to bring the patient to admit that it could be true. To this end the autobiographic method aimed at understanding oneself, the sequence of events in one's life and one's wishes and anxieties helped him.

The events went on, the divorce proceeding was to take place in court. Only then did Mr. J. believe the reality and in the subsequent phase started to search for guilt in himself. Out of principle he ascribed some sort of indeterminate guilt to himself, which he was unable to name and which he did not even understand. He looked for it and defended himself against it at the same time: "I did not drink, did not go to pubs. I didn't stay late at work. I did not neglect work in the house. I didn't hurt anybody. I didn't go anywhere." In his free time he worked - in the garden, in front of the house, he dug sewage, scraped snow, cut wood, picked fruit. When all was done he went to help his wife's parents. He loves his family, so he tried to provide for them. In this phase he was trying to save the image of himself as a good husband. The therapeutic work was aimed at becoming conscious of emotions containing self-evaluation. A meaningful response to guilt is reparation. But the problem was that Mr. J. had received no feedback from his wife concerning the reasons for her decision to divorce, was incapable of reflection himself and the wife did not desire reparation. The time for internal dialogue on a life crossroads, a detached view or de-reflection had not yet come.

With the imminent divorce his world collapsed. Sleep disorders and the combination of his personality characteristics present already in the premorbid stage, such as undifferentiated negative emotivity, high intensity of reaction, rigidity, absence of sense 
of humour and at the same time anxiety, meticulousness, pedantry and a high level of responsibility, which he felt in a broader scope than was appropriate for his person, helped the fast deepening of the depressive state on. In the relationship sphere paranoid issues began to appear since he saw himself as a permanent target of abuse and ridicule, he was afraid of his colleagues at work, was ashamed to be divorced. He tried to shift attention to his profession, which he liked to perform. The shift was so overscale that there appeared behaviour with obsedantly compulsive features in the form of compulsive repeated checking whether everything is alright at work, on his part and on the part of his colleagues. This tendency strongly reduced the already not large number of his friends and gave rise to very ambivalent emotions in relationships. His unfavourable psychological state was deepened by somatic ailments, especially headaches. The earlier diagnosed diabetes mellitus type 2 started to get worse, within a short period of time there occurred fairly significant changes in bodily mass in the direction of increase, decrease and repeated increase.

In the therapeutic framework given by life motivations there again and again appeared issues of the third motivation expressed with the question: Am I allowed to be as I am? What am I like? What should I be like that they like me? Work and family issues merged at first with fear concerning his health, later with desire to die. Issues of lack of sleep and issues of unreliable co-workers were gradually swept away, as if they had never existed, when it turned out that his wife is unyielding in her decision and will not return, as Mr. J. had hoped. It also turned out that she had been resolving to take the step for a number of months without signalling it to her husband in a measure sufficient for him. At that time she apparently decided not to communicate with him at all any more. And Mr. J.'s world collapsed again when the divorce had officially taken place. It was serious that he still had no idea of the cause of her decision. He mentioned in passing that she screamed at him that he "takes all kinds of pills". He began to recall the twenty five years of marriage and kept asking what he had done wrong: "I never reproached her for bad cooking. I cared a lot. I brought three waggon loads of wood, harvested potatoes, when the parents were still alive I helped them, helped my mother-in-law." "Her son (Mr. J.'s brother-in-law) got divorced, her daughter also got divorced, this will be the end of her, she is 82," he worried. For months he did not believe that his wife had really left. He repeatedly visited her parents and brother with the request that they talk her out of her departure. He persisted in these demanding visits of her relatives until his brother-in-law threatened to call the police. When his wife's mother had explained to him that the matter of divorce was not hers, but his wife's and his, she also did not want to speak to him again.

He lamented and could not be diverted from his lamentations. He imagined that someone must help him call her back. He imagined that I would write a letter to his wife which would force her to come back. He tried to dictate its wording to me, that I bid his wife to return to him, that he is a really good husband. I understood how hard it is for him to be without the possibility of communication, how undignified he feels when he tries to start a conversation with her and she does not answer. At the same time I understood that his wife had apparently resigned on the possibility of explaining something to him, so she solved the matter by denying communication. I tried to work on the issue what he is like, what his roles are outside of marriage, what his strength is, his possibilities and limits. He was disappointed that I did not write the letter, but tried to cooperate. When his wife got an apartment, moved away from the house and the children left with her, the fatherly role of Mr. J. faced a fairly aggressive opponent. Mr. J. wanted 
to be at least a father at all cost ("even when they don't want me"). He imagined that when the children see him cry they will persuade their mother to return. He went to see his wife and children in their new flat, brought them money and again wanted to know what he had done that she left him. She did not let him in. "It started raining, I went away in the rain. She threw the shoes out, wanted to call the police. She commanded me: You are not to come here, you will come with the money to my desk at the office." He wished that she would say: "Come more often, we'll talk it over, discuss it."

No one came to see him in the house where he remained alone for many months, only once his sixteen-year-old son did. How could he bear his crying and pressure that he should do something so that they all come back to daddy? He never came again. Mr. J. stayed alone in the house. Another important life value was shattered - the value of life. A crisis of home and a threat to its value can bring about a limit situation and place one at a crossroads. ${ }^{38}$ Only work was left for him. But in concurrence with the disintegration of his family symptoms of poor concentration appeared, he could not concentrate on work and started saying that he is sometimes ready for suicide. "I am in deep depression, I can tell that," he stated his diagnosis. According to Lukas the art of life is to leave what we had loved and at the same time retain love in the heart, to attach oneself and nonetheless be ready to detach, be open to what is at present being offered..$^{39}$ Such readiness and openness was not to be found and courage to live was slowly disappearing. In the structure of work with motivations we were forced to return to the motivation " I want to live".

Alongside his indivertible mood Mr. J. most probably ceased to be able to manage his duties and after half a year was transferred to another workplace. Besides the experience of degradation it was difficult that he had to commute for two hours a day by train to his new workplace from his home. He did not reflect on the cause of the transfer to another workplace from the point of view of reality, he only named one incident based on which, as he believed, he had been transferred: He did not sleep at night, overslept and came several minutes late to work. It was a very traumatizing failure for him, which he could not bear. Self-evaluation and self-esteem started to crumble, the ideal of exemplary worker began to fall apart. In his thoughts he mused on the situation how he would be if his wife had not left, and in accord with his enduring professional ambition and love for his work he painfully imagined how his earlier co-worker, who had received bad marks at school, now worked on his position.

At therapy he cried and requested again several times that I talk his wife out of her decision to leave. He did not want to understand the limits there are in psychotherapy. Because he kept repeating his traumatizing present, we focused on recalling, so that he would bring to consciousness the continuity of his life, all that had belonged to it, and what his life-story had in fact been like so far. He began with a memory of the school-leaving exam: "The fairy tale ends, life is beginning." The leaving exam marks were beautiful. "Now I needn't go anywhere where there is bullying," he remarked in this context, although he had denied bullying at school before. And suddenly his wife tells him today that she will never come back. "I pray that I can stand it." "One priest told me that if I took my life I would suffer twice as much." He cries. "If the Lord God took me, I would be in peace. I will not live to high age anyway, young people die."

38 Cf. Martina KOSOVÁ, Logoterapie. Existenciální analýza jako hledání cest, p. 82.

39 Cf. Elisabeth LUKASOVÁ, Logoterapie ve výchově, Praha: Portál, 1997, pp. 182-183. 
In searching for his own resources in therapy he says that if he could meet himself as he feels now, he would try to comfort himself. Comforting in his understanding meant to give himself hope that his wife would come back. He again many times returned to questioning how it could have happened when he took so much care, did not sit in the pub and always went straight home from work. When asked whether he would do things differently today he answered that he would not, "we would just reach understanding with my wife". "Lucky they didn't scratch you...," people were calling as he was leaving the housing estate where his wife and children live. It apparently was a hallucinatory processing of the trauma. He imagines that women from his town will tell their children: "Don't say hallo to him! He is divorced!" He imagines that others condemn him because his wife has left him. In his solitude he tries to get close with a man who is also alone. His sister died, his wife died, but he found another one, she also died. "And he goes on, goes on trips, goes to the mountains," says Mr. J. admiringly and does not allow that such reaction would be possible for him as well. On being asked whether he would think of also going somewhere to see something, for a walk, he is surprised why he should go somewhere when it is cold. He does not enjoy anything, but it was hopeful that he would like to tidy up at home. Later he not only did not tidy up, as he had intended, but stopped heating because there is no point heating for oneself. He did not wash clothes because his wife had taken away the washing machine. He felt lonely, nobody asked about him even when he was ill and in hospital. He cries every day. Being asked whether crying helps he answers that it probably doesn't help much, but "I will cry. I close myself up at home and cry." "I survive from day to day. I can't live alone." The shallowed emotivity which showed in personality questionnaires at that time could have been brought about by the patient's thoughts of ending his life. He started imagining that he would lie down under a train.

Relatively soon after the appearance of suicidal thoughts heart problems appeared, so that a several days long hospitalization was necessary. Periodontitis, inflammation of the gums, got worse so that he could not chew and was about to have all his teeth extracted.

He began to feel solitude very intensively: "People are coming, there are people everywhere. Nobody came to our place. Now it is at home like in a prison. Earlier I wanted first of all quiet for everything." He still does not understand why his wife left: "I wasn't a drunkard who goes round pubs, I only took care. She did not appreciate that I dragged wood and coal home." He keeps writing letters to his wife in which he admonishes and begs her to return. He is not angry with himself, he seems not to be able to find a relational plane to his wife. He doesn't say that he loves her or that he is angry with her, just that she should return, that he cannot cope without her.

Because after almost a year of psychotherapeutic work and living in a house his parents had left to him he did not make his "I can live without my wife", much less so "I want to live", we started to work more with art therapeutic creation and with imaginations. When he imagined climbing up a mountain in which it should show how he would manage the demanding journey, it went well for the first time in ages. He was interested in the landscape, he felt quite fine, had short breath, made it up to the peak. On directing attention to the fact that the difficult journey worked out well, that he had done a lot and did not give up in hardship, he answered: "So well, so." The awakening and moving power did not appear. 
Subjectively he still felt lonely after half a year, allegedly cries every day (perhaps an hour), he was crying on the train when he was coming to the consultation. Nobody had visited him for one and half years, not even his children. He started crying when he looked at his old ID which still said "married", he started crying when he was buying bread. "I am grieved, I suffer like a beast." He went around with his head down, unhappy, helpless. His life had changed a lot. Problems with diabetes not only persisted but got worse, his blood sugar level rose significantly.

He avoids people, is ashamed. What if they asked about his family?! The theme of shame turned out to be of life-long importance. It also had to do with his father's bad work injury. His father had never reconciled to its consequences and perceived his life as worthless. The theme "things ought to be different than they are" and themes of the self-worth of Mr. J. collide and merge with the unprocessed (and at present unprocessable) themes of first and second motivation, i.e., "cannot and does not want to live". He can't imagine that he could. He has not accepted his present life without his wife. He lacked security, lacked space and support.

\subsection{Two years later}

When winter was approaching again Mr. J. did not take of his short nylon trousers. His shoes got worn over the summer, they are unsewn, the sole will soon get torn off. Mr. J. does not wash (he did not get a new wash-machine also for financial reasons). He will not hear of social assistance. On this "threat" he decided to wash his jeans. I realized that it was necessary to divert the therapeutic effort from the current trauma and work on possibilities of change first behaviourally and then by deeper immersion into the emotional sphere. Although he cries, his emotionality seems not to exist. Only emotionality could perhaps play a part in perceiving the answer to the question of meaning of life. Even though there is a very strong positive link between positive emotions and experience of life meaning, ${ }^{40}$ the absence of positive emotions does not at the same time mean absence of meaning, but meaning can be attained also in a situation when positive emotions are completely lacking, by the path of accepting suffering. ${ }^{41}$ But the valency of emotional states is determined by personal goals. And Mr. J.'s goal was not "that I may be better" but "that my wife returns, only then will I be better".

After almost two years of therapy Mr. J. manifested in test materials markedly "increased score of depressivity and psychosomatic disturbance issuing most probably from helplessness, which he still feels in connection with the break-up of his marriage and collapse of life values and wishes. Adequate ability to cope with stimuli is lacking, there are still a number of associated neurotic symptoms, emotional lability, or negative emotivity, aggressiveness and lachrymosity. The attention system is significantly disrupted (hypoprosexy). A consequence of the present state is an inhibition of volitional processes, disturbed insight, nihilism, anhedony and higher level of social dysfunction. The grave phenomenon of loss of identity has appeared." 42

Over the previous year the process of professional as well as common personal functioning had been disrupted. The above symptoms contributed to a number of psychoso-

40 Cf. Peter TAVEL, Zmysel života podla Viktora Emanuela Frankla, Bratislava: Iris, 2004, p. 56.

41 Cf. Viktor E. FRANKL, Viole ke smyslu, p. 136.

42 Excerpts from aimed psychological examination (Lhotová). 
matic ailments and generally minimally actualized life bodily regulation. His prospective tension together with learned helplessness was at the root of the fear that he would not take care of himself. It was apparent that the situation was at present really heading towards that.

Compensation mechanisms to reduce anxiety are not found even in interpersonal relations and personality preconditions. "The risk is low differentiation in interaction. A further risk factor are accentuated personality characteristics - dependent personality style, in which reduced access to self-representations combines with self-neglect - approaching the diagnosis Dependent personality disorder. Mr. J. is unable to form a long-term harmonious balance of his needs, since his needs are ever again fixed on the unrealizable return of his ex-wife. Together with a high level of certain obduracy and rigidity in connection with life events the patient is at present fairly resistant to psychotherapy." 43

His problematic, highly ambivalent relationship to people is witnessed by his hypothetical wish in a topic induced in imagination, which was to change his name. He would change it to the most common one occurring in this country - Jan Novák. Although he himself certainly does not have an extraordinary name attracting attention, he wants to be even more common with the statement "people would leave me in peace".

Diabetes, breathing problems, weariness, lack of concentration, hospitalization, disability pension. Illnesses were piling up and he cried, cried incessantly. He remained inaccessible to reasoning of any kind. He tortured himself by bringing the alimony to his ex-wife's new home personally, rather than sending it by post. The wife and children did not let him in, they took the money through a slot in the door. At that it remained.

He came to therapy ever more neglected, dirty, in short nylon trousers in winter, with shoes worn so that they barely held together. He did not heat his house. Why should he? There was no one there. His self was not of such value that it should be warm. He was ashamed to go out in the street. Everybody would think: That's the one whose wife ran away. His life lacked elements of order of any kind and especially any kind of fulfilment, any kind of meaning not consisting in the permanent wish for the wife's return. When disability pension was granted to him he cut the roses in his garden, allegedly because they were too much work. Just when he had received disability pension had he begun to lack time? He started to bring something self-destructive to every therapeutic session, containing the implicit call: "Do something at last, that she returns!" The corruptive, emptying power of solitude began to oppress me. There was no dialogical exchange, the "structure of meaning" collapsed.

He has a place to stay - a house with a garden. But these seem to have become a burden for him. He is angry with the places in his house where there is mould, where something is out of order. His "I can live" is tied to his family. And to his wife, precisely to this, at present his former wife, who will cook for him and will silently watch over his sleep, whatever it is like. Further, his "I can live" is or was tied to the performance of his profession. He lost these two conditions of his life in a certain parallel process.

How to lead him to the understanding that he can be even in the present situation, that 
he can find security in his space and start looking for support, if precisely this woman is not and does not want to be with him? With that it remains. He does not want to kill himself, he is Catholic, but he keeps imagining it. But fortunately he is ill. He believes that if his health is very poor, perhaps his wife and children will have pity on him.

\subsection{What Mr. J.'s value system was like}

In Mr. J.'s life satisfaction derived from work and family life. He held his education and work in high esteem. His goal was to precisely fulfil his duties. He renders his memories of his earlier life - in the family and at work - in idealized form according to his idea of how the things around him ought to have been on his view. Work with imagination and relationship to life helped to understand the fact that Mr. J. is confused when his co-workers don't fulfil their duties, is relentless in that they should fulfil them, but at the same time too weak to enforce it. In the marital relationship it was similar. Mr. J. is confused that his wife has not fulfilled her duty to be with him, is relentless in his requirement that she redress it, but is too weak for it. He imagines that the "wife will cook and wash, I will do the hard work and arrange things".

The relational level of rejection, incomprehensible for him, probably begins with the fact that people did not accept him as he is. He is a rigid man, non-adaptive, pedantic, without the ability to laugh. Is his life good? Here the differences show between value of life as such, perceived value of life on the religious conception, perceived value of own life, value of life in the conditions he had wished for, value of life with someone; all this in a reflection of the fact that he really did not hurt people, but nonetheless they didn't want him. He could not understand why.

In work with emotions he could not name what he feels when he is crying. Sorrow, pity, helplessness or childish obstinacy and wrath at being denied something he wants? In work with identity he could not perceive his own self, he shared it with his wife or at least with his profession. It is in fact a concurrence of triple identity: The self is constituted by wife and children and profession. Without it he would "not be". From his point of view one cannot be without the other. But his profession can be without him, his wife and children can be without him. He himself feels more than incomplete without his family and work, he himself has become pain and grief.

The fourth condition of existence presupposes assenting to the previous three. He himself spontaneously tried to look for solution or support on the spiritual level without assenting to the preceding motives. But again he was seeking something that would return his wife to him. He addressed the priest in the parish, from whom he apparently expected something like he had expected from me, i.e., that he could help him to persuade his wife to return. The Catholic Church does not support divorce, does it? After a time of listening the priest showed him the reality, which he did not intend to respect and did not have the strength to do so any more. He was unable to step outside of himself and view the situation from a different perspective and at least minimally accept what had happened to him. He was angry with the priest because he must help him, mustn't he? The people whom he kept telling about his misfortune and with whom he cried with an unspoken request for help stopped listening to him. Living without saying yes to life is exhausting, it takes much strength and experience of value is impossible. Values can become tyrannical when one does not want to take a straight look at reality, which in this case were desertion, divorce and loneliness. Protracted grief resulted in a 
decline of strength for possibilities of realistic reactivation and integration of the individual struggle into the course of events in a relationship network.

His deep depressive state had reached chronicity, so did anxiety in the form of prospective tension, and dependence in the form of inability to take care of himself led to rejecting life. He persisted in wailing over the unanswered question why it had happened. In this state he rejected hospitalization, rejected social assistance and terminated therapy. It wasn't clear whether the termination means resignation, loss of hope or whether his departure is an understanding and a good sign that he would try alone.

A fundamental difference in attitude to life can be expressed in two sentences. "I don't want to live like this," says the first one. The other is "I don't want to live at all". One generally passes into the other and could, if reality is accepted, show a prospect of eventual realistic reorientation, ${ }^{44}$ in which one begins again to attend to new or old values, when he again begins to consider the circumstances and context of his life. Mr. J. did not find anything in his life that would have meaning for him. He perceived ridicule from others. Grief and defence drove anxiety to panic. The last unconscious attempt to live was the switch from deep depression to a manic state, when he again made an appointment for therapy. The manic state was full of feverish activity. Mr. J. tried everything he had not tried before: sit in a car and drive on sidewalks, fight in the pub, seek a new wife (and break the path through to values again), fill himself with laughter, make jokes. But he could really do none of that, all took place in a changed state of consciousness, it was laughter of helplessness and without joy, it all crossed the limits of adequacy. His life took a changed, aberrant and dangerous form and the result was hospitalization in a psychiatric department.

\section{Analysis of casuistry}

\subsection{Reflection I - Losses}

Existential analysis describes four great areas in which our life takes place. It is the family, the world of work, the world of interpersonal relationships, and the world of own self. ${ }^{45}$ The psychotherapy which had been conducted with the patient before his wife left him took place systematically and thematically was concerned mostly with work and interpersonal relations, within the concept of basic motivations then working on relationship to the future. Mr. J. considered the family to be a stable certainty. He gradually lost all this. Personal outlook into the future, which personal existential analysis strives for, disappeared, it was not accepted in such form as it was perceived. Mr. J. lost all prospect in life, first did not want, later lost the strength to look for it, as well as to do anything else.

The depth of life, harmony with oneself and with the world can be felt by experiencing closeness, time and relationships. ${ }^{46}$ These experiences constitute the fundamental value of being, the deepest feeling of value of life. In these contexts depression is explained by the fact that if even only one of these experiences is missing, there appears first desire, then coldness and finally

44 Cf. Karl RUEHL, Setkání s postiženým člověkem, in: Žít svůj vlastní život: Úvod do existenciální analýzy, ed. Silvia LÄNGLE - Martha SULZ, Praha: Portál, 2006, p. 173.

45 Cf. ibid, p. 173.

46 Cf. ibid, pp. 173-174. 


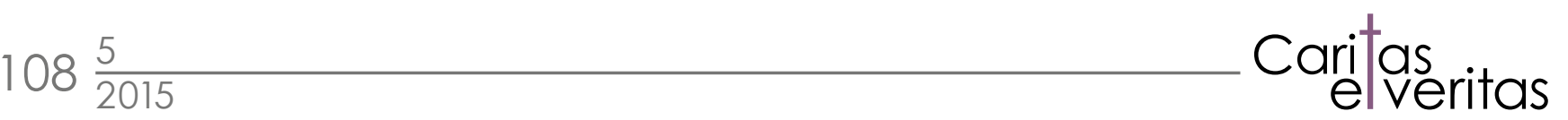

depression. Frankl speaks of the will to humour as an attempt to see things in a lighter perspective as a weapon in the struggle for self-preservation. ${ }^{47}$ Basic value thus experienced represents the foundation of what we perceive as value. Mr. J. did not have humour on his repertoire, he never laughed, the ability to see things in a lighter perspective was probably missing already premorbidly. Bauer mentions the problem of personality deficiency functioning as an obstacle to understanding meaning and subsequent problems in therapeutic work with experience and creating the dialogue I-world. ${ }^{4}$ He speaks of a type of personality disorder (para-existentielle Persönlichkeitsstörung) with blocked existential motivations etiologically linked to crisis of identity and fixation without the ability of self-distance and opening up to the world. Instead of dialogue with the real world, these persons become fixed on a construction or idea of the world, which they project onto reality.

\subsection{Reflection II - To have something to live for}

Mr. J. began therapy with a simply conceived commission related to helping him sleep well. The next commission was his wife's return. As a result of his hope that it could happen with my assistance he was inaccessible to any kind of reflection of reality. Already in the phase of creating the second commission there was an unrealizable intention. I gradually lost hope in the possibilities of helping him. He gradually lost the hope that his wife would return, which he had invested in psychotherapy, and all four basic life motivations collapsed.

In Mr. J. the "have something to live for" was shattered, self-transcendence was blocked, he did not blame God, but did not understand. All that was left of his faith in God was the determination not to kill himself, because as a Christian he is not allowed to. Thus exposed to the world, with damaged will, he fell into despair. He became without relationship only in the manic phase. The original relationship with his former wife disappeared, the wish that she returns disappeared, but he did not find a new relationship. A human being without a relationship to a human being loses relationship to her life. In his eyes success of the psychotherapy was linked to the return of his wife, which would return value to his life.

His relationship to the future changed in that it ceased to contain possibilities of becoming and development, but arose in front of him as something uncertain, imminent, dangerous, eventually as something empty. In relation to the past existential analysis points to the fact that even the present can affect the past and give new meaning to it, it admonishes one to come to terms with it. The reality of what had happened in the past cannot be revoked, but how we integrate it in our present life and what meaning it gains for it depends on the present living. ${ }^{49}$ But for Mr. J. the future had closed and he was left without hope.

\subsection{Conclusion of casuistry analysis: how effective existential analysis and logotherapy is}

One of the basic requirements for a good psychotherapeutic framework is considered to be stipulating a goal on which the patient and the psychotherapist agree. In this respect the existential model does not differ in any way from other important psychotherapeutic theories. Already this first presupposition encountered difficulties due to the difference between the patient's goal and the therapist's goal. A unified formulation of the goal (commission) was not

47 Cf. Viktor E. FRANKL, Člověk hledá smysl: Úvod do logoterapie, Praha: Nakladatelství Jiřího Kocourka, 1964, p. 33.

48 Cf. Emmanuel J. BAUER, Wenn die Sinnhaftigkeit des Sinns in Frage steht. Ansätze eines „postmodern“ erneuerten Sinnverständnisses in der LT/EA (II. Teil), Existenzanalyse 3/2000, p. 55.

49 Cf. Christine WICKY, Časovost jako výzva k pravé existenci, p. 58. 
reached. The way in which the patient was informed that psychotherapy could not help in that his wife returns was insufficient for his merely selective understanding, due most probably to acute trauma.

Little attention was paid to the depth of pain resulting from loss, experiencing this pain in time, the specific vulnerability and type of defence mechanisms of the patient. The combination of these aspects caused conflict between the requirements for coming to terms with the situation ("such is life") and the patient's possibilities in the time he needed to come to terms with the stress. Every individual experiences the pressure of the human lot in a highly individual way. Neither of the parties to the psychotherapeutic relationship had expected such heavy emotional load and "brutality" of the situation, on both sides it was too unpleasant to face crying and decreased viability. On neither side was there willingness to allow more time for the individual phases of experiencing losses and limits.

In the existential referential framework it was desirable to rigorously examine various problems leading to helplessness and work on creating own experiencing and understanding oneself with emphasis on freedom, choice, purpose and values, rather than fulfilling requirements.

\section{Conclusion}

What would this life be if it meant a value in itself and if its whole value did not consist precisely in that it can be sacrificed for something else, ${ }^{50}$ states Frankl in connection with the suffering in concentration camps, and shows such unconditional meaningfulness behind all that apparent meaninglessness of suffering and sacrifice in concentration camps that it comprises even the meaning of suffering, sacrifice and death. In the view of existential analysis the human being feels the value of life in its depth in the experience of closeness, time and relationships in harmony with the world and oneself. These experiences constitute the basic value of being, the deepest feeling of value of life. This basic value manifests itself in all experiencing, it tints feelings and emotions and is the background of what we perceive as "value", all emotions, the internal experience of life testifies to the value of life itself. The value of life shows in the course of the individual life and at the same time in observing the course of life and fates of others.

The value of life based on a relationship to one's own personal life is given by accepting it. It testifies to the touch of being and to all that occurs in that, i.e., to the emotional relationship to being as foundation of the personal life feeling - feeling of life. Life lets us know what its value is by means of experiences. It invites the human being to take part in it. ${ }^{51}$ In the words of Längle, by experiencing the value of life we "experience something that transcends us. This value does not depend on us and is not created but us, it is granted to us." 52 Basic value consists a) of the vital (primitive) quality "to love life", which one feels in her own corporeity and frame of mind and b) of "to feel oneself" based on contact with the world. It therefore comprises both the subjective and the objective pole. Whether we detect it with openness and gratitude is a possibility and a gift.

50 Cf. Viktor E. FRANKL, Viole ke smyslu, p. 15.

51 Cf. Alfried LÄNGLE, Smysluplně žít: Aplikovaná existenciální analýza, p. 44.

52 Ibid, p. 45. 


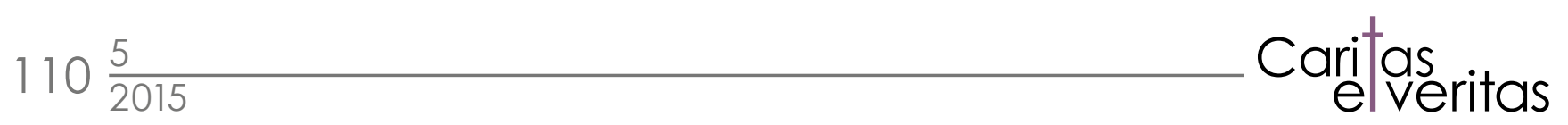

Only overall accommodating acceptance of life as a whole with all that belongs to it enables us to distinguish in the terrain of life. Antonín Mokrejs ${ }^{53}$ speaks of the difference between mere life as a life routine and inertia and good life as breaking the inertia and habit based on a question concerning its meaningfulness and justification. According to him we acquire this when we acquire the experience of conflict of life possibilities and necessity of choice.

In this paper we have distinguished between logotherapeutic psychotherapeutic approaches and approaches of existential analysis and on analysis of one case study have shown the framework in which the thought of this orientation was therapeutically organized.

I thank PhDr. Jana Božuková, MUDr. et PhDr. Alfried Längle and Doc. Karel Balcar for permission to quote from texts prepared for logotherapy and existential analysis training in SLEA in Prague.

\section{The Existentially Analytical Approach to Value of Life}

Abstract Concepts such as purpose, conscience, existence, being and life are associated with the existential psychotherapeutic approach in psychotherapy. At present it turns out that the existential approach is a valuable, effective psychotherapeutic paradigm based on rational, coherent and systematic methods, although the foundations of the existential orientation are not empirical but intuitive. The aim of the present text is to find especially in the theory of V. E. Frankl and A. Längle support for defining the value of human life and dignified being and with a particular casuistry demonstrate the conceptual framework in which the thought of this approach was therapeutically organized.

Keywords Existential Analysis, Logotherapy, Life, Value, Purpose

53 Cf. Antonín MOKREJŠ, Filosofie a život - život a umění, Praha: Filosofia, 1995. 